УДК 37.091:378

Малихін Олександр Володимирович

доктор педагогічних наук, професор, завідувач кафедри романо-германських мов і перекладу

Національний університет біоресурсів і природокористування України, м. Київ, Україна

ORCID ID 0000-0001-6042-6298

malykhinalex1972@gmail.com

Ярмольчук Тарас Михайлович

аспірант кафедри методики навчання та управління навчальними закладами

Національний університет біоресурсів і природокористування України, м. Київ, Україна

ORCID ID 0000-0002-7715-1443

bamper601@gmail.com

\title{
АКТУАЛЬНІ СТРАТЕГІЇ НАВЧАННЯ У ПРОФЕСІЙНІЙ ПІДГОТОВЦІ ФАХІВЦІВ 3 ІНФОРМАЦІЙНИХ ТЕХНОЛОГІЙ
}

\begin{abstract}
Анотація. У статті здійснено науково-теоретичні узагальнення психолого-педагогічних особливостей підготовки ІТ-фахівців та відображено комплексну діагностику процесу їхньої фахової підготовки. На основі проаналізованої й узагальненої обробки отриманих результатів визначено й ранжеровано сукупність актуальних стратегій навчання XXI століття та вектори їхньої реалізації, спрямовані на підвищення ефективності фахової підготовки студентів ІТ-спеціальності, на грунті створення відповідних дидактичних умов. Описано дидактичні можливості реалізації навчальних стратегій у процесі професійної підготовки майбутніх фахівців. На підставі отриманої теоретичним і практичним шляхом інформації обгрунтовано доцільність імплементації результатів дослідження на практиці та сформовано стратегічну модель підготовки ІТ-фахівця в контексті реалізації навчальних стратегій. Запровадження запропонованої моделі створює умови для поліпшення якості підготовки фахівців в галузі ІT, оскільки їхній стан залежить від інформаційнотехнологічної готовності, від цілей використання комп'ютера, від виду професійної діяльності. Формування у фахівця здатності до розуміння й вільного застосування інформаційних технологій i використання їх для адаптації в мінливому середовищі, нарощування власного ресурсу для вирішення нових завдань дає змогу підготувати фахівця, який вільно орієнтується на ринку праці. Застосування результатів дослідження в процесі підготовки ІТ-фахівців надасть змогу викладачам-новаторам ураховувати індивідуальнопсихологічні особливості студентів, а також специфіку конкретних професійних груп, індивідуалізувати навчальний процес $з$ метою формування професійної самостійності на основі активації реалізації сучасних стратегій організації та здійснення навчання. Представлені результати дослідження підготовки фахівців 3 інформаційних технологій передбачають перспективу подальших досліджень, зокрема розробки шляхів формування готовності майбутніх фахівців з інформаційних технологій до реалізації індивідуальних стратегій навчання в професійній діяльності.
\end{abstract}

Ключові слова: інформаційні технології; професійна підготовка; психолого-педагогічні особливості; ІТ-фахівці; стратегії навчання.

\section{1. ВСТУП}

Постановка проблеми. За останні десять років відбулися глобальні зміни в структурі індустрії інформаційних технологій, які, безумовно, спричинили видозміну вимог роботодавців до кандидатів на базові позиції в IT-сфері. Інформаційні технології швидкими темпами стають одним з основних будівельних блоків сучасного суспільства i є одним 3 ключових чинників, що впливають на якість вищої освіти. Технологічна й інформаційна глобалізація диктує міжнародні стандарти та вимоги до кваліфікації фахівців і, відповідно, до національних систем підготовки кадрів. 
Важливим напрямом реформування освіти є забезпечення випускників закладів вищої освіти (3ВО) компетентностями, необхідними на ринку праці. Сьогодні існує значний дисбаланс між уміннями й навичками, які формуються в студентства, та вміннями й навичками, які потрібні на робочому місці. Значною мірою розуміння того, що освіченість працівників позитивно впливає на рівень прибутковості бізнесу, призводить до усвідомлення того, що інвестування роботодавцем у підвищення професійних компетентностей працюючих є важливою складовою розвитку бізнесу [2, c. 15]. Сучасний ринок праці вимагає від випускників ЗВО сформованих умінь розв’язувати проблеми шляхом упровадження інновацій. Глобальна поінформованість стає більш вагомою перевагою, ніж вузька спеціалізація, а вміння здобувати знання протягом життя стають важливішими за наявний постійний рівень знань. Розвинені комунікативні вміння й навички, самоконтроль і самооцінка, співпраця й використання IT на рівні досвідченого користувача зараз уже $\epsilon$ базовими вимогами до фахівців. Відповідність цим критеріям може зробити випускника університету значно більш конкурентоспроможним. У процесі отримання нових, цінних для майбутньої професійної діяльності знань і навичок, трудові ресурси мають бути гнучкими, здатними до відмови від раніше сформованих компетенцій, здатними по-новому реагувати на глобальні зміни ринку праці. Нині стала очевидною перевага інформаційної складової діяльності людей над усіма іншими іiі формами й компонентами [3], [4], [5], [6].

У сучасних умовах життєдіяльності суспільства швидкими темпами підвищуються вимоги до професіоналізму майбутніх фахівців та простежується загальний тренд затребуваності IT-спеціалістів у всіх сферах людської діяльності. Спостерігається відставання можливостей освітнього середовища від швидко мінливих технологій і засобів IT-індустрії на тлі збільшення контингенту студентів за ITнапрямами. Зростаюча роль інформатизації несе з собою низку завдань, пов'язаних із необхідністю забезпечення суспільства IT-професіоналами як в усьому світі, так і в Україні зокрема. Першою причиною цього можна назвати зростання інтелектуальної складової праці ІT-фахівців, що пов'язано, з одного боку, зі зростанням кількості різноманітних технологій, а з іншого - 3 підвищенням рівня їхньої складності. Друга причина пов'язана 3 виникненням потреби в умовно «некваліфікованій» праці комп'ютерних фахівців. В ІТ-компаніях з'явилась велика кількість рутинної роботи, досить одноманітної й монотонної, що не вимагає від фахівця глибоких різнобічних знань, а лише володіння однією будь-якою технологією та здатності тривало виконувати «прості» операції. Третьою важливою причиною є професійна підготовка фахівців у сфері інформаційної безпеки, яка стала набувати суттєвих ознак, оскільки виступає як важлива складова комплексу заходів держави щодо іiі безпеки в інформаційному просторі.

Проблеми підготовки IT-фахівців постійно перебувають у полі зору сучасного інформаційного суспільства. Наведені причини значно загострюють актуальність проблеми професійної підготовки висококваліфікованих, компетентних кадрів у сфері інформаційних технологій. Тому дослідження психолого-педагогічних особливостей професійної підготовки фахівців ІТ-напряму стає особливо актуальним в нинішніх умовах інформатизації суспільства.

Аналіз останніх досліджень і публікацій. Аналіз науково-педагогічних джерел, електронних ресурсів показує, що на сьогодні науковцями здійснено значну кількість досліджень, пов'язаних із професійною підготовкою фахівців в галузі інформаційних технологій. Ученими розглядаються різні аспекти професійної підготовки IT-фахівців, але певні аспекти вимагають подальших досліджень. Зокрема постійної уваги потребують навчальні стратегії та вектори їхньої реалізації, спрямовані на підвищення 
ефективності фахової підготовки студентів IT-спеціальності, що зумовлено швидким темпом розвитку й удосконалення інформатизації всіх ланок життєдіяльності суспільства. Так, науковці Г. Гаджієв та Р. Ільясов [1] розглядали можливості застосування інформаційних технологій у професійній діяльності майбутніх фахівців. А. Кочарян [3] досліджував й експериментально підтвердив важливість розвитку інформаційно-комунікаційної компетентності працівників, вивчав вимоги ринку праці, яким повинен відповідати випускник сучасного ЗВО в умовах інформатизації освітнього процесу [4] і тенденції розвитку вищої освіти в умовах інформаційного суспільства [5]. С. Ніколаєнко, В. Шинкарук та В. Ковальчук [6] теоретично обгрунтували й експериментально підтвердили ефективність використання big data в освітньому процесі сучасного університету. Н. Боброва [7] досліджувала особливості підготовки ІТ-спеціалістів в умовах інформатизації суспільства. А. Іванов [11] здійснював наукові розвідки 3 питання інформаційних технологій в освіті. Н. Стрекалова [12] досліджувала, експериментально перевірила й теоретично обгрунтувала застосування хмарних технологій у професійній підготовці сучасного фахівця. В. Кухаренко, О. Рибалко та Н. Сиротенко досліджували умови дистанційного навчання. Результатами їхнього дослідження $\epsilon$ рекомендації щодо розробки та ефективного застосування дистанційних курсів. В. Биков, А. Гуржій та М. Шишкіна [15] досліджували концептуальні засади формування і розвитку хмаро орієнтованого навчально-наукового середовища навчального закладу.

Загальним проблемам професійної підготовки фахівців присвячено праці Н. Арістової, В. Бикова, І. Булах, М. Жалдака, О. Малихіна, Н. Морзе, С. Ніколаєнка.

Експлікація понять «стратегія» та «стратегія навчання» знаходить своє відображення в роботах О. Герасимової, I. Король, О. Любашенко, Л. Шерстюк, Bimmel P. [17], U. Edmondson, W. F. Glueck [16], L. R. Jauch, Klaus Stiller [18], Lompscher J., Paul D. Miller, Rampillon U. Науковець В. Ковальчук [2] досліджував стратегії інтенсифікації вищої освіти в Україні та країнах ЄС. Найбільш гучні теорії стратегій навчання пов'язані з іменем відомого видатного американського теоретика у сфері освіти Девіда Колба (David Kolb), який займається їхнім вивченням більше 40 років. Експериментальна теорія навчання науковця об'єднала актуальні дослідження 20-го століття (Джон Дьюї (John Dewey), Ж. Піаже (Piaget), Курт Левін (Kurt Lewin), К. Роджерс (K. Rogers)) та ін.

Метою статті $\epsilon$ аналіз психолого-педагогічних особливостей професійної підготовки фахівців з інформаційних технологій на основі активації реалізації сучасних стратегій організації та здійснення навчання.

\section{2. ТЕОРЕТИЧНІ ОСНОВИ ДОСЛІДЖЕННЯ}

Освітня модель підготовки IT-фахівців «4П», сформульована в ініціативі CDIO, є платформою для базової підготовки фахівців IT-напряму, що використовує системний, проблемно-орієнтований, інформаційний підходи, котрі визначають компетенції випускників, які володіють сучасними методами системного аналізу, навичками застосування відповідних теоретичних, методичних і технологічних матеріалів у процесі вирішення конкретних завдань із застосуванням тих або інших комп'ютерних технологій [7].

CDIO (Conceive, Design, Implement, Operate / Вигадуй, Розробляй, Впроваджуй, Керуй) - основний принцип інноваційного освітнього середовища, спрямованого на підготовку нового покоління інженерів, зокрема в галузі IT. Компетентності майбутніх IT-спеціалістів у галузі техніки й технологій, які формуються як результат засвоєння освітніх програм ЗВО, визначаються CDIO Syllabus i класифікуються за чотирма основними розділами. Дванадцять Стандартів CDIO визначають філософію програм 
підготовки випускників до комплексної інженерної діяльності, зокрема діяльності ITфахівців, висувають вимоги до формування навчального плану, освітнього середовища й умов навчання, методів навчання, а також методів оцінки результатів навчання студентів і програм у цілому.

З 2016 року в Україні реалізується проєкт Європейські освітні ініціативи. Проєкт спрямований на розвиток IT-освіти та інтеграцію кращих світових практик у систему підготовки IT-фахівців. Мета проєкту - забезпечити кожного бажаючого якісною сучасною освітою у сфері інформаційних технологій, допомогти IT-фахівцям бути конкурентоспроможними та гарантовано працевлаштованими [8].

Онлайн сервіс тестування й сертифікації IT-фахівців testprovider.com дає можливість перевірити себе на відповідність вимогам і визначити рівень конкурентоспроможності спеціаліста. Ресурс буде корисний як для тих, хто готується до першої співбесіди у великій компанії і хоче якнайкраще себе проявити, так і для досвідчених співробітників, які бажають завжди підтримувати свій рівень компетентності. Фахівець за допомогою онлайнсервісу має змогу пройти тестування, щоб визначити свій рівень підготовки й шанси зайняти бажану позицію в IT-компанії своєї мрії [9].

Важливим аспектом у процесі професійної підготовки майбутніх IT-спеціалістів $\epsilon$ здатність вільно працювати 3 програмними продуктами, адаптованими для користувачів-початківців. Це надає змогу вийти 3 одновимірного IT-освітнього простору та перейти до багатовимірного IT-простору, повну альтернативу та вільний вибір власної стратегії професійної діяльності [10]. На думку Н. Боброва, особливість такого навчання передбачає розвиток критичного мислення, конструктивність, асоціативність, евристичність, які допоможуть формулювати й розв'язувати нестандартні завдання сучасного суспільства на основі системного мислення, розуміння ролі й місця інформаційних процесів у природі та суспільстві [7].

Інтенсивна робота в умовах інформаційного комфорту активізує пізнавальну діяльність студента та посилює творчі компоненти педагогічної праці педагога. У нинішніх реаліях професійного навчання рухоме зображення, моделі й інші види анімації, які реалізуються за допомогою комп'ютерних технологій, застосовуються все частіше для розвитку пізнавальних прийомів і способів дій: аналіз проблемної ситуації, виявлення на цій основі зв'язків і закономірностей, що забезпечують функціонування тієї чи іншої системи. Такий ефект навчання досягається за рахунок використання моделюючих програм, що дають змогу перевести досліджуваний об'єкт у візуальну форму, які найчастіше більш успішно виконують функцію інтерпретації, ніж наближені й частково оброблені фотографії, зображення, оскільки «бачити властивості якого-небудь предмета - значить сприймати його як приклад утілення певних загальних понять».

Успішне застосування комп'ютерних технологій й отримання за їхньою допомогою продуктивних результатів навчання підвищує впевненість майбутнього фахівця стосовно здатності планувати складні професійні завдання, а також забезпечує ділову спрямованість, точність і акуратність, котрі можуть бути перенесені й в інші галузі діяльності. Студент із суб'єкта навчання перетворюється на суб'єкт професійної діяльності. Це обумовлено тим, що комп'ютер у майбутній професійній діяльності стає невід'ємним інструментом роботи випускника.

Професіоналізація студента як процес оволодіння спеціальністю та просування до iï вершин забезпечує реалізацію стратегії до самореалізації в навчальній праці. Бачення студентами стратегії досягнення вершин професійної майстерності передбачає проходження ними певних етапів, кожен 3 яких знаменує досягнення нових рівнів професійної компетентності, а саме: професійного становлення; забезпечення стабільності в роботі; сходження до професійної майстерності. 


\section{3. РЕЗУЛЬТАТИ ДОСЛІДЖЕННЯ}

У результаті дослідження визначено вхідний рівень готовності студентів вищої школи IT-напряму до реалізації навчальних стратегій XXI століття. Сутністю дослідницької роботи стало визначення сукупності навчальних стратегій, що сприятиме підвищенню ефективності фахової підготовки студентів ІТ-спеціальності на грунті створення сукупності дидактичних умов, а саме: визначення й ієрархічне впорядкування структурних компонентів змісту фахових дисциплін (цільового, стимулювально-мотиваційного, операційно-діяльнісного, контрольно-регулювального, рефлексивного) відповідно до цілей фахової підготовки студентів IT-галузі; активізація навчальної діяльності студентів засобами розв’язання педагогічних ситуацій на основі структурування їхнього змісту, що зумовлює формування загальнонавчальних умінь $\mathrm{i}$ навичок (організаційних, інтелектуальних, рефлексивних, комунікативних) та відповідних професійних якостей і компетентностей; спрямування структурування на: а) визначення найважливіших для особистісного розвитку та фахової підготовки студентів прийомів і методів роботи; б) пошук і фіксацію послідовності їхньої реалізації з урахуванням методологічної ролі в процесі навчання.

Під дидактичними умовами реалізації актуальних стратегій навчання у процесі фахової підготовки студентів ІТ-спеціальностей розуміємо науково обгрунтовані дії, відповідно до яких відбір масиву основної навчальної інформації, яка $є$ в змісті фахових дисциплін, буде здійснюватися найбільш оптимально.

Базою для визначеної сукупності навчальних стратегій стали навчальні дисципліни: «Інформаційні системи та технології», «Інженерна та комп’ютерна графіка», «Сучасні комп'ютерні технології».

Задля виявлення навчальних стратегій, спрямованих на психолого-педагогічний процес підготовки IT-фахівців, здійснено комплексну діагностику процесу фахової підготовки студентів IT-спеціальності за допомогою сукупності діагностичних методів і методик (опитування, анкетування, спостереження, бесіди, аналіз педагогічних ситуацій, вивчення продуктів навчання тощо). Діагностика здійснювалась на базі Національного університету біоресурсів і природокористування України. До процесу здійснення діагностики було залучено 264 студенти факультету інформаційних технологій.

\section{Стратегії професійної підготовки IT-фахівців}

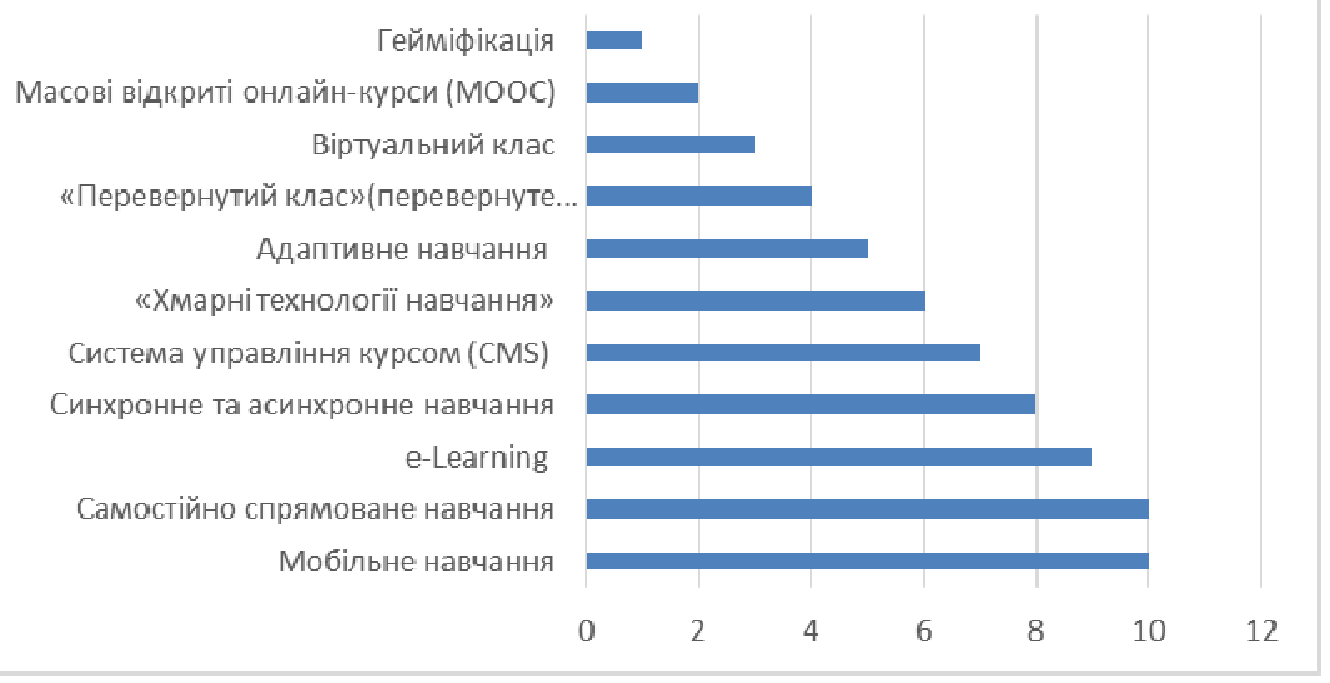

Рис. 1. Стратегї̈ професійної підготовки IT-фахівиів 
У процесі дослідження визначено три вектори реалізації навчальних стратегій до фахової підготовки IT-спеціалістів. Перший пов'язаний з урахуванням методологічних положень управління навчальною діяльністю студентів; другий - зі специфікою вивчення студентами IT-спеціальностей циклу фахових дисциплін; третій - iз дидактичною та психологічною природою підготовки IT-фахівців.

Застосована комплексна діагностика, аналіз і обробка отриманих результатів надали змогу виокремити й ранжувати стратегії професійної підготовки IT-фахівців.

- Гейміфікація. Значний розвивальний ефект у підготовці фахівців мають комп'ютерні ігри. Гейміфікація - це процес використання ігрового мислення й динаміки ігор для залучення аудиторії й вирішення поставлених завдань, перетворення чого-небудь на гру.

Застосування комп'ютерних ігор під час навчання дозволяє використовувати їх просторові функції, такі як компенсаторне спостереження, отримання інформації від численних об'єктів, розподілених у просторі, віртуальне обертання об'єктів. Можна стверджувати, що в умовах застосування комп'ютерних ігор у професійній підготовці фахівців розвивається важлива якість спеціаліста - активна творча уява. Уява виникає в проблемній ситуації, і цінність іï полягає в тому, що вона дає змогу прийняти рішення і знайти вихід із ситуації навіть при відсутності потрібної повноти знань, які необхідні для здійснення процесу мислення.

Не менш важливим для майбутньої професійної діяльності IT-фахівця вважається наявність розвинутої пам'яті. I. Бурлаковим встановлено ефективність застосування стратегічних комп'ютерних ігор для розвитку пам'яті студента, завдяки яким майбутні фахівці набувають здібностей системного аналітика [10]. Студенти навчаються швидко

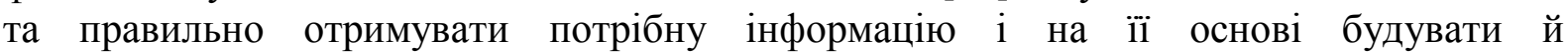
використовувати відтворені образи у вирішенні поставлених завдань.

- Масові відкриті онлайн-курси (МООС) - це нова популярна технологія онлайн-навчання, яка постійно розширює потенціал відкритих освітніх ресурсів i дистанційних освітніх технологій, може бути спрямована й використана для проєктування індивідуальної стратегії навчання студентів, зокрема IT-спеціальностей.

Онлайн-курси проводять провідні світові університети та освітні організації. Викладачами масових курсів $є$ кращі у своїй галузі фахівці та дослідники, а аудиторія провідних освітніх платформ відвідується мільйонами користувачів. Найпопулярніші MOOC представлено на таких платформах, як Coursera, Edx, Udacity i багатьох інших. Такий вид курсів надає змогу майбутнім IT-фахівцям відкрити для себе нові галузі знань, підготуватися до іспитів, пройти курс перепідготовки, підвищити кваліфікацію або просто задовольнити цікавість.

- Віртуальний клас. Віртуальний клас - це навчальне онлайн середовище, розміщене в мережі Інтернет з наявним вмістом навчальних матеріалів й організованою сукупністю онлайн-інструментів, спрямованих на процес здійснення професійної підготовки фахівців.

Підготовка IT-фахівців за допомогою віртуального класу, який поєднує в собі елементи традиційного очного навчання 3 елементами самостійного електронного навчання, надає можливість студентам i викладачам спілкуватися синхронно, реалізовуючи такі функції: аудіо, відео, текстовий чат, інтерактивні дошки, а також спільне використання додатків. Навчальні заняття можуть проводитися 3 дому, лабораторії навчального закладу або будь-якого іншого відповідним чином обладнаного місця. За умов очного навчання в аудиторії, студент і викладач одночасно заходять до віртуальної кімнати та працюють з навчальним матеріалом, викладач показує студентові текст (зразки програмного коду, алгоритми програмування), ілюстрації та презентації (будову мереж, комунікаційного обладнання) на інтерактивній 
дошці, які одночасно з'являються в електронному блокноті студента. Прикладом віртуального класу є Інтернет-сервіс «Google клас».

- «Перевернутий клас» (перевернуте навчання). Перевернутий клас - це форма змішаного навчання, за допомогою якої «основне засвоєння нового матеріалу студентами відбувається вдома, а час аудиторної роботи виділяється на виконання завдань, вправ, проведення лабораторних i практичних робіт тощо» [2, с. 58]. Перевернуте заняття базується на конструктивістській моделі навчання. У цій моделі навчання $\epsilon$ активний, соціальний процес, у якому студенти IT-напряму мають можливість застосовувати наявні знання й накопичений досвід для створення індивідуального розуміння нового матеріалу. Крім того, у цій моделі викладач виступає в якості консультанта, студенти та викладач стають партнерами. Фактично з'являється можливість працювати зі студентом один на один.

3 точки зору таксономії навчання за допомогою «Перевернутого класу» студенти виконують нижній рівень пізнавальної роботи за межами аудиторії, а більш високі рівні пізнавальної роботи в лабораторії закладу освіти. У сфері інформаційних технологій студенти мають змогу отримати максимальну віддачу аудиторного часу, витрачаючи його на практичне застосування. Час, який вивільняється в процесі здійснення «перевернутого навчання», викладач має змогу використати для розгляду складних моментів, які виникають у процесі підготовки IT-фахівців. Обдаровані студенти матимуть більше свободи для того, щоб навчатись у власному темпі, а викладач матиме змогу приділити більше уваги тим студентам, яким важко засвоїти навчальний матеріал або у яких виникають проблеми з виконанням практичних робіт.

- Адаптивне навчання. За дослідженнями професора В. Ковальчука «в основу адаптивного навчання покладено принципово нову модель організації навчання. Організаційна структура лекції або лабораторно-практичного заняття за цієї моделі дає змогу збільшити термін самостійної роботи студентів, що, своєю чергою, потребує переходу до безперервного управління, яке забезпечує надійну реалізацію на практиці основних положень теорії діяльності. Навчання як один з видів діяльності людини в умовах адаптивної моделі навчання (АМН) стає переважно активною самостійною діяльністю, яка керується за допомогою навчальних і контролюючих програм, сітьових планів і графіків самообліку» [2, с. 24].

Адаптивна стратегія навчання спрямована на забезпечення ефективної, дієвої, індивідуальної стратегії навчання з метою залучення кожного студента до самостійної діяльності. Суть цієї методики полягає в тому, що ефективність заняття значно підвищується, коли викладач не лише спостерігає за самостійною роботою студентів за комп’ютером, а й працює в цей час з окремими студентами індивідуально.

У процесі професійної підготовки ІТ-спеціалістів у середовищі адаптивного навчання структура лекційних, лабораторно-практичних $\mathrm{i}$ семінарських занять забезпечує можливість майбутнім фахівцям на кожному наступному занятті продовжити діяльність 3 урахуванням індивідуальних особливостей кожного 3 них, умов цієї діяльності. На занятті викладач навчає, демонструє, пояснює, показує, а потім працює в індивідуальному режимі з кожним студентом. Студенти за таких умов мають можливість працювати у трьох режимах: разом 3 викладачем; 3 викладачем індивідуально, самостійно під керівництвом викладача. Самостійна робота студентів продовжується вдома.

- «Хмарні технології навчання». Розвиток «Хмарних технологій»є актуальним прикладом утілення нового вектору розвитку діяльності суспільства в сфері інформаційних технологій. Функціонування «Хмари» передбачає раціональний розподіл, віддалену обробку та безстрокове зберігання завчасно завантажених даних. «Хмарні технології» $є$ великим інформаційним центром або мережею взаємопов'язаних 
серверів, доступ до яких здійснюється через Інтернет-з'єднання за допомогою спеціалізованого програмного забезпечення. За такої умови організації роботи 3 програмним забезпеченням користувач не використовує ресурси власного персонального комп'ютера, а покладає всі функціональні обов'язки на необмежені комп'ютерні ресурси та потужності Інтернет-сервісу. У процесі професійної підготовки IT-фахівців «Хмарні технології» дають можливість забезпечити загальний доступ до збереженої в «Хмарі» інформації з будь-якого місця та пристрою; безкоштовно використовувати спеціалізовані додатки, спрямовані на обробку інформації (текстові, табличні, графічні редактори, програми для створення презентацій та ін.), механізми індивідуальної та колективної роботи (віртуальні кабінети, диски, пошта); швидкий обмін інформацією з будь-якою кількістю користувачів (розсилки, форуми, спільноти та ін.). Прикладами сучасних сервісів, побудованих на основі «Хмарних технологій» для освіти, є Live@edu від Microsoft i Google Apps Education Edition.

Педагогічно виважене та доцільне запровадження в освітній процес «Хмарних технологій», формування і розвиток навчально-наукового середовища на цій основі $\epsilon$ суттєвим чинником підвищення ефективності застосування IT, поліпшення їхнього позитивного впливу на якість професійної підготовки фахівців [15].

- Система управління курсом (CMS) - це пакет програмного забезпечення, що дає змогу створювати й поширювати навчальні матеріали (презентації, посібники, підручники, завдання до лабораторних і практичних робіт, замітки, завдання, тести та ін.) і розміщувати їх в Інтернеті без використання HTML або іншої мови програмування.

CMS забезпечена сукупністю інструментів, призначених для розробки й завантаження контенту курсу, а також має широкий спектр утиліт для резервного копіювання, відновлення звітності навчальної діяльності студентів. Для кожного студента система генерує стартову сторінку зі списком курсів, на яких навчається майбутній фахівець, надає можливість викладачам створювати й управляти курсами, розробляти завдання, заходи, вікторини, тести й багато чого іншого, доступного в інтерактивному середовищі. Студенти можуть увійти в систему та працювати в будьякий час, у будь-якому місці, адже в системі наявні інструменти для здійснення синхронного й асинхронного навчання, а також мають змогу скористатися навчальними матеріалами курсів, які вони вивчали в попередніх семестрах, якщо адміністрація курсу надає до них доступ. Прикладами CMS, які можна застосовувати для процесу підготовки фахівців IT-сфери, є: Moodle, MaxSite CMS, Drupal, Joomla, (системи мають українську локалізацію); OLAT; Interact; Docebo; Wordcircle; e107; RedDot; Microsoft CMS; Rhythmyx; Documentum; Open pages; Chrystal Software; Viagnette; CyberTeams; Blue Martini; Tikiwiki CMS Groupware.

- Синхронне та асинхронне навчання. Синхронне навчання здійснюється в режимі реального часу й передбачає одночасну участь викладача й студента, студента й студента, розділених лише територіально. Зв'язок здійснюється за допомогою мережі Інтернет та спеціалізованого програмного забезпечення, онлайн сервісів. За такої форми практично імітується звичайний навчальний процес, оскільки передається як аудіо, так і відеозображення від викладача до студента й навпаки. Досить розповсюджене в рунеті поняття «вебінар» $\epsilon$ вираженим прикладом синхронного навчання. Найбільш відомі програми для синхронного навчання: Interwise Webex (Cisco), Adobe Connect, Elluminate, Instant Presenter.

Асинхронне навчання підтримує діалог викладача зі студентами протягом певного періоду часу й забезпечує майбутніх фахівців усіма можливими навчальними матеріали, необхідними для формування професійних якостей майбутніх робітників у зручний для кожного студента час протягом певного встановленого викладачем 
терміну. До переваг такого навчання належить можливість використовувати велику кількість мультимедіа разом 3: відео, комп'ютерними програмами, зображенням, звуком; широкий спектр тестів для контролю знань; можливість захистити паролем матеріали для аутентифікації та збереження привілеїв авторського права; можливість навчатися на відстані, у будь-якому місці в будь-який зручний час.

- e-Learning - навчання, що грунтується на використанні інформаційних i телекомунікаційних технологій, які надають можливість підтримувати весь процес навчання: від доставки навчальних матеріалів студентам до їхнього контролю рівня засвоєння [13]. На відміну від навчання за допомогою Інтернету і мультимедіа, що передбачає використання дистанційних курсів, які пропонуються студентам 3 метою організації процесу навчання, e-Learning 2.0 передбачає використання засобів Веб 2.0: блогів, вікі, підкастів, соціальних мереж тощо [14].

Спираючись на структуру побудови й функціонування e-Learning 2.0, В. Кухаренко вказує такі його специфічні якісні властивості [15]: гнучкість навчального процесу і його адаптивність до потреб і можливостей студентів, які в основному не відвідують регулярні заняття, а працюють у зручний (як для викладача, так і для студента) для такої роботи час у зручному місці та зручному темпі; модульність побудови навчальних програм; нову роль викладача: координування викладачем навчально-пізнавального процесу, коригування курсу, який викладає, керування навчальними проєктами, перевірка поточних завдань, консультування під час складання індивідуального навчального плану, управління навчальними групами взаємопідтримки; спеціалізовані форми контролю якості навчальних досягнень: традиційні форми контролю якості освіти та дистанційні (співбесіди, практичні, курсові та проєктні роботи, екстернат, робота в середовищі комп'ютерних інтелектуальних тестових систем тощо); використання спеціалізованих засобів навчання.

У зв'язку з тим, що навчання за допомогою Інтернету й мультимедіа останніми роками набуває все більшої популярності, застосовувати технологію е-Learning 2.0 у процесі професійної підготовки фахівців є актуальним.

- Самостійно спрямоване навчання. Самостійна робота $\epsilon, 3$ одного боку, різновидом діяльності, що стимулює активність, самостійність, пізнавальний інтерес, $є$ основою самоосвіти, поштовхом до подальшого підвищення кваліфікації, а 3 іншого системою заходів чи педагогічних умов, що забезпечують керівництво самостійною діяльністю студентів.

Самостійно спрямоване навчання згідно 3 твердженнями науковців В. Ковальчука, О. Малихіна - це процес отримання знань, за реалізації якого студент сам приймає рішення, без сторонньої допомоги або з нею, формулює цілі, яких хоче досягти, визначає людські та матеріальні джерела знань, обирає та здійснює освітню стратегію й оцінює отримані знання [2, с. 62].

Студенти IT-спеціальностей, які навчаються самостійно, не звертаються до професійних фахівців у тому разі, коли вони навчились самостійно вирішувати свої навчальні проблеми, майже не користуються допомогою професіоналів. Очевидно, що використання ресурсів мережі Інтернет певною мірою подібне до консультації викладача й допомоги однокурсників, тому спостерігається зворотна кореляція 3 повністю самостійним вирішенням проблеми. Показником зрілості професійної самостійності можна вважати здатність студентів IT-спеціальностей розв' язувати свої проблеми самостійно із застосуванням навчальних ресурсів і сервісів глобальної мережі Інтернет.

- Мобільне навчання. У реаліях сьогодення комп'ютерна техніка у поєднанні з мережею Інтернет стали необхідними освітніми інструментами, які з плином часу стали більш портативними, доступними, ефективними та простими у використанні, що 
відкриває широкі можливості для їхньої реалізації в освітньому процесі, зокрема в професійні підготовці фахівців для ІТ-галузі.

Мобільне навчання - це можливість отримати навчальні матеріали на персональні пристрої (КПК, смартфони, планшети та мобільні телефони). Якщо розглянути термін «Мобільне навчання» у більш широкому контексті, слід визнати, що мобільні технології $€$ зсувом парадигми формування знань у житті суспільства i тому характер навчання (формального й неформального) передбачає створення мобільними технологіями величезних можливостей для реалізації нових форм навчання, оскільки вони змінюють характер фізичних відносин між викладачами, студентами, об'єктами та суб' єктами навчання.

На основі результатів дослідження й отриманої теоретичним шляхом інформації маємо необхідні та достатні підстави обгрунтувати доцільність імплементації дослідження та сформувати дидактичну модель досліджуваного феномену підготовки IT-фахівців на основі реалізації навчальних стратегій.

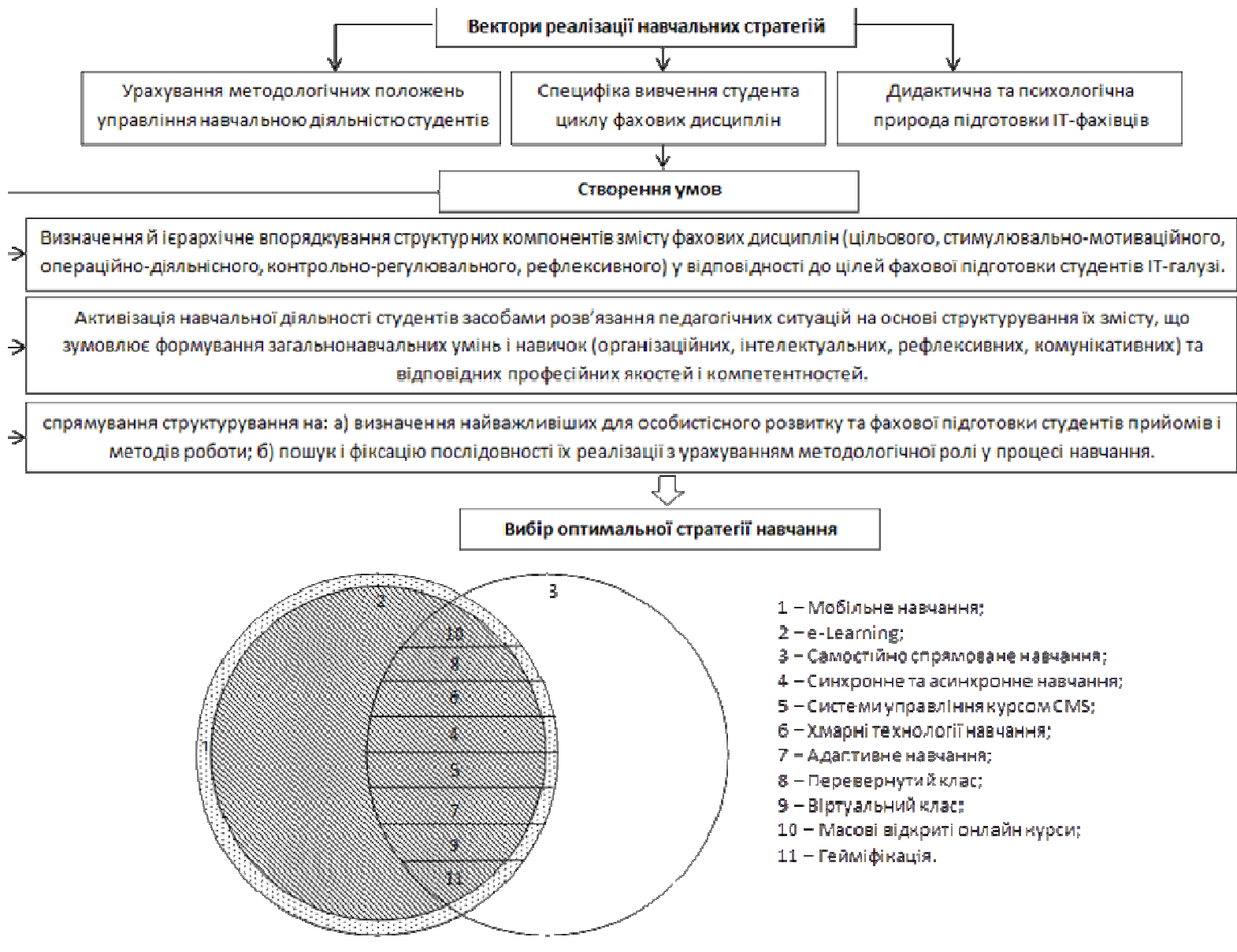

Рис. 2. Стратегічна модель підготовки ІТ-фахівців

У запропонованій моделі (див. рис. 2) відображено внутрішню логіку формування в студентів індивідуально-особистісного стилю пізнавальної діяльності, детерміновано вибором індивідуальної стратегії пізнавальної діяльності, розробкою індивідуального дидактичного маршруту та просування означеним маршрутом завдяки алгоритмізації окремих навчальних дій, виконанням вправ і практичних завдань різних видів, самостійної роботи, підібраних з урахуванням індивідуальних особливостей студента та кола його пізнавальних інтересів. Самостійний вибір стратегії пізнавальної діяльності й індивідуального дидактичного маршруту є оптимальними зовнішніми 
організаційними формами для формування індивідуально-особистісного стилю пізнавальної діяльності студентів. Вибір стратегії професійної підготовки IT-фахівців укладається шляхом визначення напряму підготовки IT-спеціаліста, компетентностями, якими має оволодіти майбутній фахівець, добором засобів і методів, спрямованих на підготовку фахівця. «Рухаючись» індивідуальним дидактичним маршрутом i виконуючи вправи та завдання, студенти повинні зануритися в їхню сутність, вибрати оптимальні шляхи своїх дій, пояснити або довести їхню правильність або правомірність.

Варіативно стратегічна модель підготовки IT-фахівців щодо формування індивідуально-особистісного стилю пізнавальної діяльності студентів (див. рис. 2) відбиває не тільки загальну логіку професійної підготовки майбутнього IT-спеціаліста, а й логіку майбутньої професійної діяльності фахівця, який має надати ціннісне забарвлення знанням, що засвоюються, системної організованості й особистісного сенсу, оскільки інформаційні технології й комп'ютерна техніка постає не лише як засіб навчання, а й як інструмент професійної діяльності майбутнього фахівця.

\section{4. ВИСНОВКИ ТА ПЕРСПЕКТИВИ ПОДАЛЬШИХ ДОСЛІДЖЕНЬ}

Науково-теоретичні узагальнення та напрацьований емпіричний матеріал, представлені в роботі, надають об'єктивні верифіковані підстави для формування висновку. Результати проведеної роботи вказують на те, що сучасні тенденції розвитку світового освітнього процесу характеризуються застосуванням різноманітних навчальних стратегій, в основі яких здебільшого лежить застосування інформаційних технологій. Застосування сучасних інформаційних технологій розширює потенційно можливі межі реалізації освітнього процесу та сприяє створенню комбінованого освітнього середовища, у якому студент перетворюється на активного учасника навчального процесу, а викладачі діють як експерти й консультанти, допомагаючи аналізувати та вирішувати його проблеми.

Визначено сукупність навчальних стратегій, що сприятиме підвищенню ефективності фахової підготовки студентів ІТ-спеціальності на грунті створення сукупності дидактичних умов, а саме: визначення й ієрархічне впорядкування структурних компонентів змісту фахових дисциплін (цільового, стимулювальномотиваційного, операційно-діяльнісного, контрольно-регулювального, рефлексивного) відповідно до цілей фахової підготовки студентів IT-галузі; активізація навчальної діяльності студентів засобами розв'язання педагогічних ситуацій на основі структурування їхнього змісту, що зумовлює формування загальнонавчальних умінь $\mathrm{i}$ навичок (організаційних, інтелектуальних, рефлексивних, комунікативних) та відповідних професійних якостей і компетентностей; спрямування структурування на: a) визначення найважливіших для особистісного розвитку та фахової підготовки студентів прийомів і методів роботи; б) пошук і фіксацію послідовності їхньої реалізації з урахуванням методологічної ролі в процесі навчання.

На основі визначеної сукупності навчальних стратегій розроблено стратегічну модель підготовки IT-фахівців. Навчальний процес на основі реалізації запропонованої моделі створює умови для поліпшення якості підготовки фахівців галузі IT. Психічні процеси, властивості, стан фахівців залежать від інформаційно-технологічної готовності, від цілей використання комп'ютера, від виду професійної діяльності, тому формування у фахівця здатності розуміння й вільного застосування інформаційних технологій і використання їх для адаптації в мінливому середовищі, нарощування власного ресурсу для вирішення нових завдань дозволяють отримати фахівця, який вільно орієнтується на ринку праці. Відтак у процесі відбору інформаційних технологій 
для професійного навчання слід враховувати індивідуально-психологічні особливості студентів, а також специфіку конкретних професійних груп. Інноваційний підхід до навчання студентів у сфері IT-технологій вимагає індивідуалізації навчального процесу 3 метою формування професійної самостійності на основі активації реалізації сучасних стратегій організації та реалізації навчання: мобільного навчання, e-Learning, самостійно спрямованого навчання, синхронного та асинхронного навчання, системи управління курсами CMS, хмарного навчання, адаптивного навчання, перевернутого класу, віртуального класу, масових відкритих онлайн курсів, гейміфікації.

Перспективою подальших розвідок $\epsilon$ розроблення шляхів формування готовності майбутніх фахівців 3 інформаційних технологій до реалізації індивідуальних стратегій у професійній діяльності. 3 цими кластерами тісно взаємопов'язаний кластер дидактичної мобільності, яка тлумачиться як здатність переважно самостійно визначати стратегію пізнавальної діяльності та змінювати ії в разі потреби, обирати й оптимально використовувати форми, засоби, прийоми навчальної діяльності залежно від загального контексту навчальної взаємодії, наявного технічного забезпечення навчального процесу, власної суб' єктності.

\section{СПИСОК ВИКОРИСТАНИХ ДЖЕРЕЛ}

[1] Г. Гаджиев, Р. Ильясов, “Информационные технологии в профессиональной подготовке специалиста”, Омский научный вестник, №4(58), с. 187-189, 2007.

[2] В. Ковальчук, О. Малихін, Н. Арістова, Р. Попов та І. Гриценко, Стратегії інтенсифікації вищяої гуманітарної освіти в Украӥні та краӥнах СС: монографія, Київ, Україна: НУБіП України, 2017.

[3] А. Кочарян, "Розвиток інформаційно-комунікаційної компетентності науково-педагогічних працівників гуманітарних спеціальностей класичних університетів”, дис. канд., наук., Iн-m iнф. тех. $і$ засобів навч., Київ, 2016.

[4] А. Кочарян, “Требования рынка к выпускникам современных университетов в условиях информатизации учебно-воспитательного процесса", на II науч.-практ. конф. Инновационные тендениии развития системы образования, Чебоксары, 2014.

[5] А. Кочарян, “Тенденції розвитку вищої освіти в умовах інформаційного суспільства”, Між. наук.практ. конф. Україна-Польща: стратегічне партнерство в системі геополітичних координат, Київ, 2017.

[6] С. Ніколаєнко, В. Шинкарук та В. Ковальчук, "Використання big data в освітньому процесі сучасного університету”, Інформаційні технології $і$ засоби навчання, №4, с. 239-253, 2017.

[7] Н. Боброва, “Особенности подготовки it-специалистов”, IV Межд. науч.-практ. конф. Инновационные процессы и корпоративное управление, Минск, 2013, с. 65-67.

[8] “Проект європейські освітні ініціативи”. [Електронний ресурс]. Доступно: https://mon.gov.ua/ua/ osvita/visha-osvita/suchasna-it-osvita-v-ukrayini. Дата звернення: Лютий 27, 2018.

[9] "Професійні стандарти для IT спеціалістів". [Електронний ресурс]. Доступно: https://edu.cbsystematics.com/ua/news/10241. Дата звернення: Лютий 23, 2018.

[10] Т. Ярмольчук, “Формування і реалізація індивідуальних стратегій професійної підготовки фахівців вищої кваліфікації як психолого-педагогічна проблема”, ХІІІ межд. науч. прак. конф. Найновите постижения на европейската наука - 2017, София, 2017, с. 46-48.

[11] А. Иванов, “Информационные технологии в образовании”, Межд. конф., Москва, 2010. [Електронний ресурс]. Доступно: http://msk.ito.edu.ru/2010/section/64/2289/index.html. Дата обращения: Янв. 29, 2018.

[12] Н. Стрекалова, “Облачные технологии в профессиональной подготовке современных специалистов”, Научный диалог, №7(43), с. 63-74, 2015.

[13] "E-Learning”, E-Coфm Девелопмент, 2011. [Електронний ресурс]. Доступно: http://www.weblearn.ru/index.php?option=com_content\&view=article\&id=36:e-learning\&catid=12:biblioteka online\&Ite mid= 17. Дата обращения: Янв. 27, 2018.

[14] В. Кухаренко, О. Рибалко та Н. Сиротенко, Дистаниійне навчання: Умови застосування. Дистанційний курс. Харків, Україна: “НТУ ХПІ”, 2015.

[15] В. Биков, А. Гуржій та М. Шишкіна “Концептуальні засади формування і розвитку хмаро орієнтованого навчально-наукового середовища закладу вищої педагогічної освіти”, Сучасні інформаційні технології та інноваційні методики навчання в підготовці фахівців: методологія, 
теорія, досвід, проблеми, $2018 . \quad$ [Електронний ресурс]. Доступно: http://www.vspu.net/ojs/index.php/sit/article/download/341/341. Дата звернення: Вересень 28, 2018.

[16] W. Glueck, and L. Jauch, Business Policy and Strategic Management, New York: McGraw-Hill, 1988

[17] P. Bimmel, and U. Rampillon, Lernerautonomie und Lernstrategien, Fernstudienprojekt zur Fort- und Weiterbildung im Bereich Germanistik und Deutsch als Fremdsprache, Goethe-Institut München, 2000.

[18] K. Stiller "Lernstrategien und Lernerfolg beim computerbasierten Wissenserwerb". [Електронний pecypc].

Доступно:https://www.researchgate.net/publication/29861601_Lernstrategien_und_Lernerfolg_beim_co mputerbasierten_Wissenserwerb. Дата звернення: Вересень 28, 2018.

Матеріал надійшов до редакиї̈ 03.11.2018 p.

\title{
АКТУАЛЬНЫЕ СТРАТЕГИИ ОБУЧЕНИЯ В ПРОФЕССИОНАЛЬНОЙ ПОДГОТОВКЕ СПЕЦИАЛИСТОВ ПО ИНФОРМАЦИОННЫМ ТЕХНОЛОГИЯМ
}

\author{
Малыхин Александр Владимирович \\ доктор педагогических наук, профессор, заведующий кафедрой романо-германских языков и перевода \\ Национальный университет биоресурсов и природопользования Украины, г. Киев, Украина \\ ORCID ID 0000-0001-6042-6298 \\ malykhinalex1972@gmail.com
}

\section{Ярмольчук Тарас Михайлович}

аспирант кафедры методики обучения и управления учебными заведениями

Национальный университет биоресурсов и природопользования Украины, г. Киев, Украина

ORCID ID 0000-0002-7715-1443

bamper601@mail.ru

\begin{abstract}
Аннотация. В статье представлено научно-теоретические обобщения психологопедагогических особенностей подготовки ИТ-специалистов и отображено комплексную диагностику процесса их профессиональной подготовки. На основе проанализированной и обобщенной обработки полученных результатов выделено и ранжировано совокупность учебных стратегий и векторы их реализации, направленные на повышение эффективности профессиональной подготовки студентов ИТ-специальности на почве создания соответствующих дидактических условий. Описано дидактические возможности реализации учебных стратегий в процессе профессиональной подготовки будущих специалистов. На основании полученной теоретическим и практическим путем информации обосновано целесообразность имплементации результатов исследования на практике и сформировано стратегическую модель подготовки ИТ-специалиста в контексте реализации учебных стратегий. Введение предложенной модели создает условия для улучшения качества подготовки специалистов в области ИТ, поскольку их состояние зависит от информационно-технологической готовности, от целей использования компьютера, от вида профессиональной деятельности. Формирование у специалиста способности к пониманию и свободного применения информационных технологий и использование их для адаптации в изменчивой среде, наращивание собственного ресурса для решения новых задач позволяют получить специалиста, который свободно ориентируется на рынке труда. Применение результатов исследования в процессе подготовки ИТ-специалистов позволит преподавателям-новаторам учитывать индивидуально-психологические особенности студентов, а также специфику конкретных профессиональных групп, индивидуализировать учебный процесс с целью формирования профессиональной самостоятельности на основе активации реализации современных стратегий организации и реализации обучения. Представленые результаты исследования подготовки специалистов по информационным технологиям предусматривают перспективу дальнейших исследований, в частности разработки путей формирования готовности будущих специалистов по информационным технологиям до реализации индивидуальных стратегий в профессиональной деятельности.
\end{abstract}

Ключевые слова: информационные технологии; профессиональная подготовка; психологопедагогические особенности; ИТ-специалисты; стратегии обучения. 


\title{
TOPICAL STRATEGIES IN THE PROFESSIONAL TRAINING FOR INFORMATION TECHNOLOGIES SPECIALISTS
}

\section{Oleksandr V. Malykhin}

Doctor of Pedagogical Sciences, Professor, Head of the Department of Romance and Germanic Languages and Translation

National University of Life and Environmental Sciences of Ukraine, Kyiv, Ukraine

ORCID ID 0000-0001-6042-6298

malykhinalex1972@gmail.com

\section{Taras M. Yarmolchuk}

Postgraduate student of the Department of Methods of Teaching and Management of Educational Institutions National University of Life and Environmental Sciences of Ukraine, Kyiv, Ukraine

ORCID ID 0000-0002-7715-1443

bamper601@mail.ru

\begin{abstract}
The article provides scientific and theoretical generalizations of psychological and pedagogical features of IT specialists training as well as complex diagnostics of their professional training process. On the basis of the analyzed and generalized results, the authors define and rank a set of training strategies and vectors of their implementation aimed at improving the efficiency of IT students' professional training within the terms of providing corresponding didactic conditions. Attention is paid to didactic possibilities for implementing training strategies in the process of professional training of prospective specialists. Based on the information obtained by theoretical and practical means, the paper substantiates the need for the implementation of the study results in practice. Moreover, a strategic model for IT specialist training in the context of training strategies is formed. The implementation of the suggested model creates conditions for improving the quality of IT specialists training, because their condition depends on the information technology readiness, on the purpose for using a computer, on the type of professional activity. Developing a specialist's ability to understand and freely use information technologies for the sake of adaptation in a changing environment, increasing their own resources to solve new problems, one can get a specialist who is freely oriented on the labour market. Application of the study results in the process of IT specialists' training will allow educators to take into account students' individual psychological characteristics, as well as the specifics of concrete professional groups, to individualize the learning process in order to form professional independence, based on the implementation of modern training strategies. In terms of the prospects for further research the authors suggest that the ways of the formation of prospective IT specialists' readiness for the implementation of individual training strategies in professional activity should be developed.
\end{abstract}

Keywords: information technology; professional training; psychological and pedagogical features; IT specialists; training strategies.

\section{REFERENCES (TRANSLATED AND TRANSLITERATED)}

[1] G. Gadzhiev, and R. Il'jasov, "Information technology training specialist", Omskiy nauchnyiy vestnik, №4(58), s. 187-189, 2007. (in Russian)

[2] V. Kovalchuk, O. Malykhin, N. Aristova, R. Popov, and I. Hrytsenko, "Stratehii intensyfikatsii vyshchoi humanitarnoi osvity v Ukraini ta krainakh YeS: monohrafiia", Kyiv, Ukraine: NUBiP Ukrayiny, 2017. (in Ukrainian)

[3] A. Kocharian, "The development of information and communication competence of scientific-pedagogical workers of humanitarian specialities of classical universities", dis. Cand., Sciences., Inst. of INF. tech and media studies., Kyiv, 2016 (in Ukrainian)

[4] A. Kocharian, "Market demand for graduates of modern universities in the conditions of Informatization of the educational process", in II nauch.-prakt. konf. Innovacionnye tendencii razvitija sistemy obrazovanija, Cheboksary, 2014. (in Russian)

[5] A. Kocharian, "Development trends of higher education in the information society", in Mizh. nauk.-prakt. konf. Ukraina-Polshcha: stratehichne partnerstvo v systemi heopolitychnykh koordynat, Kyiv, 2017. (in Ukrainian)

[6] S. Nikolaienko, V. Shynkaruk, and V. Kovalchuk, "The use of big data in the educational process of a modern University”, Information Technologies and Learning Tools, №4, s. 239-253, 2017. (in Ukrainian) 
[7] N Bobrova, "Peculiarities of training of it-specialists", in IV Mezhd. nauch.-prak. konf. "Innovatsyonnye protsessy i korporatyvnoe upravlenye», Minsk, 2013, s. 65-67. (in Russian)

[8] "The project of the European education initiative". [Online]. Available: https://mon.gov.ua/ua/osvita/vishaosvita/suchasna-it-osvita-v-ukrayini. Accessed on: February 27, 2018. (in Ukrainian)

[9] "Professional standards for IT professionals". [Online]. Available: https://edu.cbsystematics.com/ua/news/10241. Accessed on: February 23, 2018. (in Ukrainian)

[10] T. Yarmolchuk, "Development and implementation of individual strategies of professional training of specialists of higher qualification as psychological and pedagogical problem", in XIII mezhd. nauch. prak. konf. Nainovyte postyzhenyia na evropeiskata nauka - 2017, Sofyia, 2017, s. 46-48. (in Ukrainian)

[11] A. Ivanov "Informacionnye tehnologii v obrazovanii", in Mezhd. konf., Moskva, 2010. [Online]. Available: http://msk.ito.edu.ru/2010/section/64/2289/index.html. Accessed on: January 29, 2018 (in Russian)

[12] N. Strekalova, "Cloud technologies in professional training of modern specialists”, Nauchnyj dialog, №47 (43), s. 63-74, 2015. (in Russian)

[13] "E-Learning", E-Soft Development, 2011. [Online]. Available: http://www.weblearn.ru/index.php?option=com_content $\&$ view=article \&id=36:e-learning\&catid= $12: \quad$ bibl iotekaonline\&Itemid= 17. Accessed on: January 29, 2018. (in Russian)

[14] V. Kukharenko, O. Ribalko, and N. Sirotenko "Distance learning: conditions of use. Distance learning course, Harkiv, Ukrayina: NTU“HPI”, Torsing, 2015. (in Ukrainian)

[15] V. Bykov, A. Gurzhij, and M. Shyshkina, "Conceptual bases for formation and development of cloudoriented educational and scientific environment of higher educational institution", Suchasni informacijni texnologiyi ta innovacijni metodyky navchannya $v$ pidgotovci faxivciv: metodologiya, teoriya, dosvid, problemy, 2018. [Online]. Available: http://www.vspu.net/ojs/index.php/sit/article/download/341/341. Accessed on: September 28, 2018. (in Ukrainian)

[16] W. Glueck, and L. Jauch, Business Policy and Strategic Management, New York: McGraw-Hill, 1988

[17] P. Bimmel, and U. Rampillon, Lernerautonomie und Lernstrategien, Fernstudienprojekt zur Fort- und Weiterbildung im Bereich Germanistik und Deutsch als Fremdsprache, Goethe-Institut München, 2000. (in German)

[18] K. Stiller "Lernstrategien und Lernerfolg beim computerbasierten Wissenserwerb".[Online]. Available: https://www.researchgate.net/publication/29861601_Lernstrategien_und_Lernerfolg_beim_computerbasi erten_Wissenserwerb. Accessed on: September 28, 2018. (in German ).

\section{(cc) BY-NC-SA}

This work is licensed under Creative Commons Attribution-NonCommercial-ShareAlike 4.0 International License. 